\title{
Chryseobacterium hispanicum sp. nov., isolated from the drinking water distribution system of Sevilla, Spain
}

Correspondence

Antonio Ventosa

ventosa@us.es

\author{
Virginia Gallego, Maria Teresa García and Antonio Ventosa
}

Department of Microbiology and Parasitology, Faculty of Pharmacy, University of Sevilla, 41012 Sevilla, Spain

\begin{abstract}
Strain VP48 ${ }^{\top}$ was isolated from drinking water during a screening programme to monitor the bacterial population present in the water distribution system of Sevilla (Spain). A polyphasic taxonomic study of the isolate resulted in its identification as a member of the genus Chryseobacterium, members of which are widely distributed in soil, water and clinical sources. However, the $16 \mathrm{~S}$ rRNA gene sequence similarity values of strain VP48 ${ }^{\top}$ to the type strains of Chryseobacterium species were $96 \%$ or lower. Furthermore, phenotypic characteristics clearly indicated that the isolate represents a novel Chryseobacterium species, for which the name Chryseobacterium hispanicum sp. nov. is proposed; strain VP48 ${ }^{\top}\left(=\mathrm{CECT} 7129^{\top}=\mathrm{CCM}\right.$ $7359^{\top}=\mathrm{JCM} 13554^{\top}$ ) is the type strain. The DNA G $+C$ content of this strain is $34 \cdot 3 \mathrm{~mol} \%$.
\end{abstract}

The genus Chryseobacterium was proposed by Vandamme et al. (1994). It belongs to the family Flavobacteriaceae, phylum Bacteroidetes and currently includes 14 species (Table 1). Two previously recognized Chryseobacterium species, Chryseobacterium meningosepticum (King, 1959; Vandamme et al., 1994) and Chryseobacterium miricola (Li et al., 2003), have been transferred recently to the genus Elizabethkingia (Kim et al., 2005b). Chryseobacterium species are widely distributed in soil, water and clinical sources (Vandamme et al., 1994).

The culturable bacterial population occurring in the drinking water of Sevilla (Spain) was studied in order to monitor the microbiological quality of the water at different points in the distribution system. Four sampling campaigns were performed during a period of 1 year, one each season. Samples of drinking water (25 l) were concentrated using a tangential flow filtration system (Filtron) and plated on plate count agar (PCA; Difco) and R2A (Difco) (Reasoner \& Geldreich, 1985). Plates were incubated at $28^{\circ} \mathrm{C}$ for 7 days and colonies with different morphologies were subcultivated to obtain pure cultures. Among the organisms isolated in this study (about 600 pure cultures), strain $\mathrm{VP} 48^{\mathrm{T}}$ was isolated on PCA during the sampling campaign of October 2003 and pure culture was obtained after subcultivation on R2A medium at $28^{\circ} \mathrm{C}$.

\footnotetext{
The GenBank/EMBL/DDBJ accession number for the 16S rRNA gene sequence of strain $\mathrm{VP}^{\top} 8^{\top}$ is $\mathrm{AM} 159183$.

API ZYM profiles of strain VP48 ${ }^{\top}$ and other Chryseobacterium and Elizabethkingia species are available as supplementary material in IJSEM Online.
}

The shape and motility of bacterial cells were observed under a phase-contrast microscope $(\times 1000$ magnification $)$ from a $24 \mathrm{~h}$ liquid culture in R2A medium. Growth at different temperatures $\left(4-40^{\circ} \mathrm{C}\right), \mathrm{pH}$ values $(\mathrm{pH} \mathrm{3-12)}$ and $\mathrm{NaCl}$ concentrations $(0-5 \% \mathrm{NaCl})$ was tested on solid and liquid R2A medium. The isolate was also tested for its ability to grow on MacConkey agar (Difco) and TSA (Difco). $\mathrm{H}_{2} \mathrm{~S}$ production was determined on Kligler iron agar (Difco). Oxidase activity was detected using a $1 \%$ solution of tetramethyl-p-phenylenediamine (Difco) (Kovacs, 1956). Catalase activity was tested by picking up a young colony and smearing it in a drop of $\mathrm{H}_{2} \mathrm{O}_{2}$. The methyl red and Voges-Proskauer reactions were performed on Clark-Lubs medium (Scharlau). Indole production was determined with Kovacs' reagent on $1 \%$ tryptone broth. Simmons' citrate test was tested on Simmons' citrate agar (Sigma). For determination of acid production from different carbohydrates, a medium containing $0.5 \%$ peptone, $0.5 \% \mathrm{NaCl}$ and $0.001 \%$ phenol red was used (Cowan \& Steel, 1974). Nitrate reduction was tested on nitrate broth containing $0 \cdot 2 \% \mathrm{KNO}_{3}$ (Skerman, 1967). Urease activity was studied on Christensen's medium (Christensen, 1946). Hydrolysis of gelatin, starch and DNA was tested on the corresponding agar media (Scharlau). Tween 80 hydrolysis was tested on R2A medium containing $1 \%$ Tween 80 and $0.02 \% \mathrm{CaCl}_{2}$. Casein hydrolysis was tested on R2A medium supplemented with $2 \%$ skim milk (Difco). Flexirubin-type pigments were detected as described by Bernardet et al. (2002). API 20NE and API ZYM strips (bioMérieux) were inoculated according to the manufacturer's instructions and incubated at $28^{\circ} \mathrm{C}$.

Phenotypic characteristics of strain $\mathrm{VP} 48^{\mathrm{T}}$ are included in the species description; they clearly support its placement 
Table 1. Differential characteristics of strain VP48 ${ }^{\top}$ and related species of the genera Chryseobacterium and Elizabethkingia

Taxa: 1, strain $\mathrm{VP}^{\mathrm{T}}{ }^{\mathrm{T}}$; 2, C. balustinum; 3, C. daecheongense; 4, C. defluvii; 5, C. formosense; 6, C. gleum; 7, C. indologenes; 8, C. indoltheticum; 9, C. joostei; 10, C. scophthalmum; 11, C. shigense; 12, C. soldanellicola; 13, C. taeanense; 14, C. vrystaatense; 15, C. taichungense; 16, Elizabethkingia meningoseptica; 17, Elizabethkingia miricola. Symbols: +, positive; -, negative; NA, no data available; W, weakly positive; V, variable; D, delayed. Data for reference species were taken from Kämpfer et al. (2003), Li et al. (2003), Hugo et al. (2003), Shen et al. (2005), Kim et al. (2005a), Young et al. (2005), Shimomura et al. (2005), de Beer et al. (2005) and Park et al. (2006).

\begin{tabular}{|c|c|c|c|c|c|c|c|c|c|c|c|c|c|c|c|c|c|}
\hline Characteristic & 1 & 2 & 3 & 4 & 5 & 6 & 7 & 8 & 9 & 10 & 11 & 12 & 13 & 14 & 15 & 16 & 17 \\
\hline \multicolumn{18}{|l|}{ Growth on/at: } \\
\hline MacConkey agar & - & + & - & - & - & + & + & + & + & - & - & - & - & $-{ }^{\star}$ & - & + & + \\
\hline $5^{\circ} \mathrm{C}$ & $\mathrm{D}$ & $\mathrm{D}$ & - & - & - & - & - & + & + & $\mathrm{D}$ & + & + & + & + & - & - & - \\
\hline $37^{\circ} \mathrm{C}$ & - & + & + & + & - & + & - & + & - & - & - & + & + & - & + & + & + \\
\hline $42{ }^{\circ} \mathrm{C}$ & - & - & - & + & - & - & - & - & - & - & - & - & - & - & - & - & - \\
\hline \multicolumn{18}{|l|}{ Enzyme activities: } \\
\hline DNase & - & + & NA & NA & NA & + & + & + & + & + & NA & - & - & + & NA & + & + \\
\hline Urease & - & - & - & - & - & - & - & - & $\mathrm{V}$ & + & - & - & - & + & - & $\mathrm{D}$ & + \\
\hline Nitrate reduction & + & + & + & - & - & + & - & - & - & - & - & - & - & - & - & - & - \\
\hline \multicolumn{18}{|l|}{ Hydrolysis of: } \\
\hline Aesculin & + & + & + & + & + & + & + & + & + & + & NA & + & + & + & + & + & + \\
\hline Tween 80 & - & + & - & NA & - & + & + & + & + & + & NA & - & + & + & NA & - & + \\
\hline \multicolumn{18}{|l|}{ Production of: } \\
\hline $\mathrm{H}_{2} \mathrm{~S}$ & - & - & - & - & - & - & - & + & - & - & - & - & - & $\mathrm{V}$ & - & - & + \\
\hline Indole & $\mathrm{W}$ & + & - & + & + & + & + & + & + & - & + & - & - & + & $\mathrm{W}$ & $\mathrm{D}$ & + \\
\hline \multicolumn{18}{|l|}{ Acid production from: } \\
\hline Fructose & + & + & + & + & NA & + & + & - & + & - & + & - & - & NA & NA & + & + \\
\hline Glycerol & + & - & + & + & NA & + & + & - & $\mathrm{V}$ & - & - & - & - & NA & $\mathrm{NA}$ & + & - \\
\hline Lactose & - & - & - & - & NA & - & - & - & - & - & - & - & - & NA & - & + & + \\
\hline Maltose & + & - & - & + & - & + & + & + & + & - & - & - & - & NA & + & + & + \\
\hline Mannitol & - & - & - & - & - & - & - & - & $\mathrm{V}$ & - & - & - & - & NA & - & + & + \\
\hline Trehalose & - & - & + & + & + & + & + & - & + & + & - & - & - & NA & + & + & + \\
\hline D-Xylose & + & - & + & - & $\mathrm{w}$ & + & - & - & - & - & - & - & - & NA & + & - & - \\
\hline $\mathrm{G}+\mathrm{C}$ content $(\mathrm{mol} \%)$ & $34 \cdot 3$ & $33 \cdot 1$ & $36 \cdot 6$ & $38 \cdot 8$ & NA & $38 \cdot 0$ & $38 \cdot 5$ & $33 \cdot 8$ & $36 \cdot 8$ & $34 \cdot 2$ & $36 \cdot 6$ & $28 \cdot 8$ & $32 \cdot 1$ & $37 \cdot 1$ & $\mathrm{NA}$ & $37 \cdot 0$ & $34 \cdot 6$ \\
\hline
\end{tabular}

${ }^{\star}$ Most strains are negative.

within the genus Chryseobacterium. Phenotypic features that differentiate strain VP $48^{\mathrm{T}}$ from other species of Chryseobacterium and Elizabethkingia are shown in Table 1. A table showing API ZYM profiles of strain $\mathrm{VP} 48^{\mathrm{T}}$ and other Chryseobacterium and Elizabethkingia species is available as supplementary material in IJSEM Online.

The 16S rRNA gene was amplified using the universal primers 16F27 and 16R1488 as described previously by Mellado et al. (1995). The almost-complete nucleotide sequence was determined by NBT-Newbiotechnic (Sevilla, Spain) using an automated DNA sequencer model 3100 (Applied Biosystems). Alignment of 16S rRNA gene sequences was carried out using the ARB software program (Ludwig et al., 2004) and phylogenetic trees were inferred using the maximum-parsimony (Kluge \& Farris, 1969), neighbour-joining (Saitou \& Nei, 1987) and maximumlikelihood methods (Felsenstein, 1981).

The almost-complete 16S rRNA gene sequence of strain $\mathrm{VP} 48^{\mathrm{T}}$ (1421 bp) was compared with sequences of related organisms retrieved from the GenBank/EMBL/DDBJ databases. Strain VP $48^{\mathrm{T}}$ was most closely related to representatives of the family Flavobacteriaceae, especially to members of the genus Chryseobacterium. The highest sequence similarity was $96.0 \%$ with Chryseobacterium indoltheticum and Chryseobacterium scophthalmum, whereas similarity values were $\leqslant 96 \%$ with the type strains of other species in the genus Chryseobacterium and $93 \cdot 9-92 \cdot 7 \%$ with members of the genus Elizabethkingia. Moreover, phylogenetic analysis clearly showed that strain $\mathrm{VP} 48^{\mathrm{T}}$ constitutes a branch that is separate from other Chryseobacterium species, although the branching patterns of the different trees were not completely stable (Fig. 1). Therefore, according to phylogenetic data, strain VP48 ${ }^{\mathrm{T}}$ could be considered to be a representative of a novel species of the genus Chryseobacterium (Stackebrandt \& Goebel, 1994).

Chromosomal DNA was isolated and purified as described by Marmur (1961). The G $+C$ content of genomic DNA was determined by the method of Marmur \& Doty (1962) using the equation of Owen \& Hill (1979). The DNA G +C 


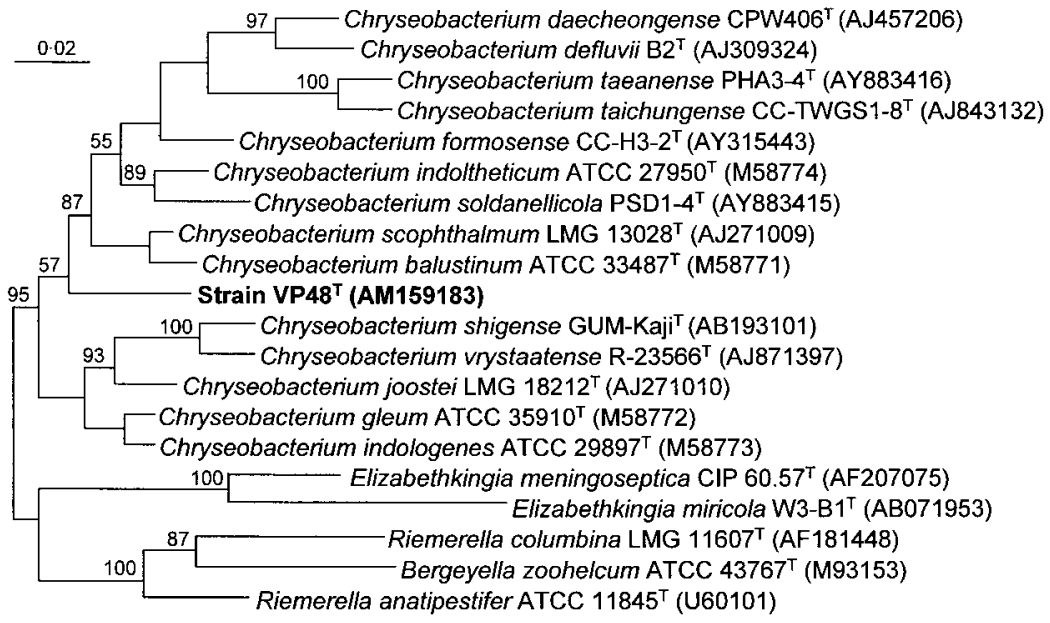

Fig. 1. Maximum-parsimony tree based on the comparison of 16S rRNA gene sequences showing the position of strain VP48 ${ }^{\top}$ and type strains of Chryseobacterium species and related species in the family Flavobacteriaceae. GenBank accession numbers are shown in parentheses. Bootstrap values greater than 50 (from 100 resamplings) are indicated at branching points. Bar, $2 \%$ sequence divergence.

content of strain $\mathrm{VP} 48^{\mathrm{T}}$ was $34 \cdot 3 \mathrm{~mol} \%$, a value that falls within the range described for the genus Chryseobacterium (Vandamme et al., 1994).

The whole-cell fatty acid composition was determined using the Microbial Identification System (MIDI, Inc.). Cells were cultured for $24 \mathrm{~h}$ at $28^{\circ} \mathrm{C}$ on TSA medium at $\mathrm{pH} 7 \cdot 0$ and cellular fatty acids were analysed using GC at the Belgian Co-ordinated Collections of Microorganisms (Laboratory of Microbiology, University of Gent, Gent, Belgium). The predominant fatty acids of strain $\mathrm{VP} 48^{\mathrm{T}}$ were summed feature 3 ( $15: 0$ iso $2-\mathrm{OH}$ and/or $16: 1 \omega 7 c, 26 \cdot 7 \%), 15: 0$ iso $(26 \cdot 1 \%)$ and $17: 0$ iso $3-\mathrm{OH}(17 \cdot 6 \%)$. Significant amounts of these fatty acids are characteristic of members of the genus Chryseobacterium (Vandamme et al., 1994). However, the fatty acid profile of strain $\mathrm{VP} 48^{\mathrm{T}}$ differs from those of other Chryseobacterium species in its larger amount of summed feature 3 and smaller amounts of 15:0 iso and $17: 1$ iso $\omega 9 c$ and in the presence of $16: 1 \omega 5 c$. A detailed fatty acid composition of strain $\mathrm{VP} 48^{\mathrm{T}}$ is given in the species description.

Phylogenetic data and several phenotypic features enabled strain $\mathrm{VP} 48^{\mathrm{T}}$ to be differentiated from other members of the genus Chryseobacterium. A novel species, Chryseobacterium hispanicum sp. nov., is therefore proposed to accommodate this strain.

\section{Description of Chryseobacterium hispanicum sp. nov.}

Chryseobacterium hispanicum (his.pa'ni.cum. L. neut. adj. hispanicum from Spain).

Gram-negative rods, $0 \cdot 9 \times 1 \cdot 5-4 \cdot 0 \mu \mathrm{m}$, occurring singly, in pairs or in short chains. Cells are non-motile and non-spore-forming. Colonies on TSA plates are whiteyellow, opaque, round, convex and $2-3 \mathrm{~mm}$ in diameter after $48 \mathrm{~h}$ at $28^{\circ} \mathrm{C}$. Strictly aerobic. Flexirubin reaction is weakly positive. Growth occurs between 5 and $30{ }^{\circ} \mathrm{C}$ (optimal growth at $25-28^{\circ} \mathrm{C}$ ) and from pH 5 to 10 (optimal

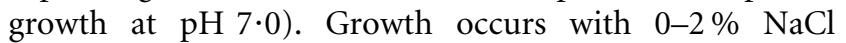
(optimal growth without $\mathrm{NaCl}$ ). Good growth occurs on R2A, PCA and TSA, but not on MacConkey agar. Positive for catalase and weakly positive for oxidase; urease activity is absent. Indole is weakly positive. Methyl red and VogesProskauer reactions are negative. Does not produce $\mathrm{H}_{2} \mathrm{~S}$. Casein, starch, aesculin and gelatin are hydrolysed, but Tween 80 and DNA are not. Simmons' citrate test is negative. Nitrate is reduced to nitrite. Acid is produced oxidatively from D-arabinose, D-fructose, D-glucose, glycerol, D-maltose, D-mannose and D-xylose, but not from D-galactose, lactose, D-mannitol or D-trehalose. Glucose fermentation is negative. D-Glucose, L-arabinose, D-mannose and D-maltose are used as sole carbon sources. $\mathrm{N}$-Acetylglucosamine, D-mannitol, potassium gluconate, capric acid, adipic acid, malic acid, trisodium citrate and phenylacetic acid are not used as sole carbon sources. Alkaline and acid phosphatases, esterase (C4), esterase lipase (C8), leucine arylamidase, valine arylamidase, cystine arylamidase, trypsin, $\alpha$-chymotrypsin, naphthol-ASBI-phosphohydrolase, $\alpha$-glucosidase and $\beta$-glucosidase activities are present. Arginine dihydrolase, lipase (C14), $\alpha$-galactosidase, $\beta$-galactosidase, $\beta$-glucuronidase, $N$-acetyl$\beta$-glucosaminidase, $\alpha$-mannosidase and $\alpha$-fucosidase activities are absent. Cellular fatty acids amounting to more than $1 \%$ are: $13: 0$ iso, $2 \cdot 5 \%$; unknown $13 \cdot 565,1 \cdot 0 \% ; 15: 0$ iso, $26 \cdot 1 \% ; 15: 0$ anteiso, $3 \cdot 6 \%$; summed feature $3(16: 1 \omega 7 c$ and/or $15: 0$ iso $2-\mathrm{OH}), 26 \cdot 7 \% ; 16: 1 \omega 5 c, 5 \cdot 3 \% ; 16: 0$, $2 \cdot 4 \%$; $15: 0$ iso $3-\mathrm{OH}, 4 \cdot 0 \%$; $17: 1$ iso $\omega 9 c, 1 \cdot 3 \%$; unknown $16 \cdot 582,1 \cdot 9 \% ; 16: 03-\mathrm{OH}, 4 \cdot 4 \%$; and $17: 0$ iso $3-\mathrm{OH}$, 
$17 \cdot 6 \%$. The DNA $\mathrm{G}+\mathrm{C}$ content of the type strain is $34 \cdot 3 \mathrm{~mol} \%$ ( $T_{\mathrm{m}}$ method).

The type strain is $\operatorname{VP} 48^{\mathrm{T}}\left(=\mathrm{CECT} 7129^{\mathrm{T}}=\mathrm{CCM} 7359^{\mathrm{T}}=\right.$ JCM $13554^{\mathrm{T}}$ ), isolated from drinking water in Sevilla, Spain.

\section{Acknowledgements}

V. G. was supported by a fellowship from the Spanish Ministerio de Educación y Ciencia. This work was supported by grants from the Quality of Life and Management of Living Resources Programme of the European Commission (QLK3-CT-2002-01972), from the Spanish Ministerio de Ciencia y Tecnología (BMC2003-01344) and from the Junta de Andalucía.

\section{References}

Bernardet, J.-F., Nakagawa, Y. \& Holmes, B. (2002). Proposed minimal standards for describing new taxa of the family Flavobacteriaceae and emended description of the family. Int J Syst Evol Microbiol 52, 1049-1070.

Christensen, W. B. (1946). Urea decomposition as a means of differentiating Proteus and paracolon cultures from each other and from Salmonella and Shigella types. J Bacteriol 52, 461-466.

Cowan, S. T. \& Steel, K. J. (1965). Manual for the Identification of Medical Bacteria. London: Cambridge University Press.

de Beer, H., Hugo, C. J., Jooste, P. J., Willems, A., Vancanneyt, M., Coenye, T. \& Vandamme, P. A. R. (2005). Chryseobacterium vrystaatense sp. nov., isolated from raw chicken in a chicken-processing plant. Int J Syst Evol Microbiol 55, 2149-2153.

Felsenstein, J. (1981). Evolutionary trees from DNA sequences: a maximum likelihood approach. J Mol Evol 17, 368-376.

Hugo, C. J., Segers, P., Hoste, B., Vancanneyt, M. \& Kersters, K. (2003). Chryseobacterium joostei sp. nov., isolated from the dairy environment. Int J Syst Evol Microbiol 53, 771-777.

Kämpfer, P., Dreyer, U., Neef, A., Dott, W. \& Busse, H.-J. (2003). Chryseobacterium defluvii sp. nov., isolated from wastewater. Int J Syst Evol Microbiol 53, 93-97.

Kim, K. K., Bae, H.-S., Schumann, P. \& Lee, S.-T. (2005a). Chryseobacterium daecheongense sp. nov., isolated from freshwater lake sediment. Int J Syst Evol Microbiol 55, 133-138.

Kim, K. K., Kim, M. K., Lim, J. H., Park, H. Y. \& Lee, S.-T. (2005b). Transfer of Chryseobacterium meningosepticum and Chryseobacterium miricola to Elizabethkingia gen. nov. as Elizabethkingia meningoseptica comb. nov. and Elizabethkingia miricola comb. nov. Int J Syst Evol Microbiol 55, 1287-1293.

King, E. O. (1959). Studies on a group of previously unclassified bacteria associated with meningitis in infants. Am J Clin Pathol 31, 241-247.

Kluge, A. G. \& Farris, F. S. (1969). Quantitative phyletics and the evolution of anurans. Syst Zool 18, 1-32.

Kovacs, N. (1956). Identification of Pseudomonas pyocyanea by the oxidase reaction. Nature 178, 703.
Li, Y., Kawamura, Y., Fujiwara, N., Naka, T., Liu, H., Huang, X., Kobayashi, K. \& Ezaki, T. (2003). Chryseobacterium miricola sp. nov., a novel species isolated from condensation water of space station Mir. Syst Appl Microbiol 26, 523-528.

Ludwig, W., Strunk, O., Westram, R. \& 29 other authors (2004). ARB: a software environment for sequence data. Nucleic Acids Res 32, 1363-1371.

Marmur, J. (1961). A procedure for the isolation of deoxyribonucleic acid from microorganisms. J Mol Biol 3, 208-218.

Marmur, J. \& Doty, P. (1962). Determination of the base composition of deoxyribonucleic acid from its thermal denaturation temperature. J Mol Biol 4, 109-118.

Mellado, E., Moore, E. R. B., Nieto, J. J. \& Ventosa, A. (1995). Phylogenetic inferences and taxonomic consequences of $16 \mathrm{~S}$ ribosomal DNA sequence comparison of Chromohalobacter marismortui, Volcaniella eurihalina and Deleya salina and reclassification of V. eurihalina as Halomonas eurihalina comb. nov. Int J Syst Bacteriol 45, 712-716.

Owen, R. J. \& Hill, L. R. (1979). The estimation of base compositions, base pairing and genome sizes of bacterial deoxyribonucleic acids. In Identification Methods for Microbiologists, 2nd edn, pp. 217-296. Edited by F. A. Skinner \& D. W. Lovelock. London: Academic Press.

Park, M. S., Jung, S. R., Lee, K. H., Lee, M.-S., Do, J. O., Kim, S. B. \& Bae, K. S. (2006). Chryseobacterium soldanellicola sp. nov. and Chryseobacterium taeanense sp. nov, isolated from roots of sanddune plants. Int J Syst Evol Microbiol 56, 433-438.

Reasoner, D. J. \& Geldreich, E. E. (1985). A new medium for the enumeration and subculture of bacteria from potable water. Appl Environ Microbiol 49, 1-7.

Saitou, N. \& Nei, M. (1987). The neighbor-joining method: a new method for reconstructing phylogenetic trees. Mol Biol Evol 4, 406-425.

Shen, F.-T., Kämpfer, P., Young, C.-C., Lai, W.-A. \& Arun, A. B. (2005). Chryseobacterium taichungense sp. nov., isolated from contaminated soil. Int J Syst Evol Microbiol 55, 1301-1304.

Shimomura, K., Kaji, S. \& Hiraishi, A. (2005). Chryseobacterium shigense sp. nov., a yellow-pigmented, aerobic bacterium isolated from a lactic acid beverage. Int J Syst Evol Microbiol 55, 1903-1906.

Skerman, V. B. D. (1967). A Guide to the Identification of the Genera of Bacteria, 2nd edn. Baltimore: Williams \& Wilkins.

Stackebrandt, E. \& Goebel, B. M. (1994). Taxonomic note: a place for DNA-DNA reassociation and 16S rRNA sequence analysis in the present species definition in bacteriology. Int J Syst Bacteriol 44, 846-849.

Vandamme, P., Bernardet, J.-F., Segers, P., Kersters, K. \& Holmes, B. (1994). New perspectives in the classification of the flavobacteria: description of Chryseobacterium gen. nov., Bergeyella gen. nov., and Empedobacter nom. rev. Int J Syst Bacteriol 44, 827-831.

Young, C.-C., Kämpfer, P., Shen, F.-T., Lai, W.-A. \& Arun, A. B. (2005). Chryseobacterium formosense sp. nov., isolated from the rhizosphere of Lactuca sativa L. (garden lettuce). Int J Syst Evol Microbiol 55, 423-426. 